\title{
GÊNERO, MEMÓRIA E DITADURA: A MILITANCIA POLÍTICA DE LÍDIA LUCASKI NO PARANÁ*
}

\author{
Gender, memory and dictatorship: Lidia Lucaski's \\ activism in Paraná
}

\section{Carla Cristna Nacke Conradi**}

\begin{abstract}
RESUMO
Este artigo aborda a relação entre gênero e ditadura ao escrever sobre a história da ditadura civil-militar no Paraná, através da memória autobiográfica de uma militante paranaense. O retorno que Lídia Lucaski faz ao seu passado foi entrelaçado por análises de seu engajamento na militância, pelo ressentimento dos abusos vividos pela violência política e policial da repressão e de como instrumentalizou o gênero para conseguir desenvolver suas tarefas políticas. Muito mais do que narrar sua trajetória, Lídia problematiza a relação que tem no presente, com sua memória, dimensionando sua capacidade de arquivar o passado ou de fazer apropriações das experiências vividas. Parte-se do pressuposto que a narrativa exprime uma necessidade de repensar a própria trajetória, cujo sujeito avalia ações e se questiona se valeu a pena ter vivido tudo o que viveu. Esse trabalho de memorização das experiências traduz o desejo de renovação interna e de afirmação de existir diferente no presente.
\end{abstract}

Palavras-chave: mulheres; militância política; memória.

\begin{abstract}
This article addresses the relation between gender and dictatorship in writing about the history of the civil-military dictatorship in Paraná, through a Paraná militant autobiographical memory. Lidia Lucaski's
\end{abstract}

\footnotetext{
* Esta pesquisa teve apoio do Coordenação de Aperfeiçoamento de Pessoal de Nível Superior - CAPES.

** Doutora em História pela Universidade Federal do Paraná. Docente do Curso de História da Universidade Estadual do Oeste do Paraná. Coordenadora do Laboratório de Estudos de Gênero - LAPEG. Orientadora pedagógica do Núcleo Maria da Penha - NUMAPE/UNIOESTE. E-mail: caconradi@yahoo.com.br
} 
retrospective was intertwined by her engagement in militancy analyses, resentment of abuses experienced by the political and police violence of repression and how she instrumentalized gender in order to carry out her political tasks. In addition to narrating her trajectory, Lidia problematizes the present, with her memory, sizing her ability to archive the past or make appropriations of her lived experiences. It is assumed that the narrative expresses a need to rethink our own trajectory, whose subject evaluates actions and wonders if it was worth having lived all that was lived. This work of memorizing experiences reflects the desire for inner renewal and affirmation of existing differently in thepresent.

Keywords: women; political activism; memory.

Um caminho inusitado de escrever a história da ditadura civilmilitar no Paraná é proposto neste artigo, que dá visibilidade ao percurso vivido pela ativista política de esquerda Lídia Lucaski. Articulando sua memória pessoal, colhida em depoimento, ${ }^{1}$ a processos coletivos, a experiência histórica sobre a ditadura no estado é relida e problematizada.

Em estudos anteriores, ao investigarmos a ação política de mulheres em luta contra a ditadura no Paraná, a partir de suas narrativas, constatamos que a manifestação da memória da resistência à ditadura é formada por situações inquietantes quando vistas a partir dos estudos de gênero. Uma delas versa sobre a invisibilidade da militância feminina na memória social da história sobre a ditadura no estado, dado o trabalho historiográfico e memorialístico em ocultar as atuações de mulheres militantes políticas (CONRADI, 2015). A estrutura dessa assertiva não se compõe pelo fato das mulheres terem participado em menor número ${ }^{2}$ se comparado à presença de homens nos espaços de resistência, ou por não terem ocupado cargos de liderança, mas pela opção de uma produção

\footnotetext{
1 LUCASKI, Lídia. 67 anos. Entrevista em 7 de novembro de 2012, Curitiba. Entrevistadora: Carla Cristina Nacke Conradi. Acervo da autora.

2 De acordo com Marcelo Siqueira Ridenti, estima-se que 600 mulheres estiveram distribuídas entre quase todas as organizações de esquerda no Brasil nos anos de 1964 a 1979. Em cerca de 40 organizações, as mulheres chegaram até a $30 \%$ do total de participantes. Na Aliança Libertadora Nacional - ALN, 15,4\% do total eram mulheres, e na Vanguarda Popular Revolucionária - VPR, eram 24,1\%. (RIDENTI, 1990).
} 
historiográfica comprometida com o patriarcado ${ }^{3}$, que interpreta as mulheres pelos estereótipos imutáveis inerentes ao feminino, como fraqueza física e emocional, ingerência de si e de um projeto coletivo; portanto, não considera suas atuações como políticas e relevantes.

Há de observar que, em nossa pesquisa, o gênero (SCOTT, 1990) entrelaça a relação entre memória e ditadura, por entendermos que, o gênero delineia a construção da memória histórica. No texto "Práticas da Memória Feminina" Michelle Perrot (1989), problematizou a possível existência de uma memória especificamente feminina e, observa que,

Não, sem dúvida, se se trata de ancorá-la numa inencontrável natureza e no biológico. Sim, provavelmente, na medida em que as práticas socioculturais presentes na tripla operação que constitui a memória - acumulação primitiva, rememoração, ordenamento da narrativa - está imbricada nas relações masculinas/femininas reais e, como elas, é produto de uma história. (1989, p. 18).

Dito de outra forma, as mulheres ao rememorarem o passado o fazem de uma forma diferente dos homens. O que não quer significar, obviamente, que as mulheres tenham capacidades mentais diferentes das deles, contudo as narrativas de mulheres se estruturam distintamente. Portanto, a partir de Perrot, sabemos que há uma forma de rememorar feminina.

Margareth Rago (1998), ao formular críticas feministas ao sujeito universal da ciência, dialogou com as observações de Perrot sobre a memória das minúcias em que o privado também é pessoal, e define também que há um modo de interrogação próprio do olhar feminino, o que poderíamos caracterizar como uma "releitura da história no feminino" (RAGO, 1989, p. 22). Portanto, conforme Rago, as mulheres trazem uma experiência histórica e cultural diferenciada da masculina, e um dos

3 Sobre a relação entre história e patriarcado, Tânia Swain estabelece: "o patriarcado, este sistema de dominação que cria e confere ao homem poderes sobre as mulheres, é também dotado de uma historicidade incontornável e considerá-lo permanente ao longo do tempo é aderir a um sistema interpretativo de crenças e valores cuja força reside em sua própria repetição" (2008. p. 30). 
motivos disso é que as práticas masculinas são mais valorizadas e hierarquizadas em relação às femininas. Nesta esteira, Rago tem debatido subjetividades femininas em contraposição a relação entre memória femininas pujantes e esquecimentos na escrita da história da ditadura no país, por entender que,

não é demais insistir sobre a importância de ouvir suas vozes e de escutar atentamente os seus depoimentos e testemunhos [das mulheres], especialmente quando desfazem as mentiras oficiais, revelam episódios que muitos gostariam de calar e expõem a nu a violência física exercida sobre seus corpos, nas prisões, em sessões de interrogatório e tortura, ou ainda, a violência simbólica em suas inúmeras dimensões. (RAGO, 2009, p. 7)

Estudos sobre memórias políticas de mulheres evidenciam que as militantes produzem formas de narrar diferentes das que estamos acostumados(as) a conhecer em relatos autobiográficos de alguns homens sobre a ditadura. Como exemplo, enfatizam o papel de outros(as) membros(as) da família em suas recordações, como seus pais, mães, irmãos(ãs), muitas delas reconstroem o passado relacionando-o com pontos de referência do ciclo de vida familiar, como casamentos, maternidades, filhos(as), com as situações vividas durante a militância, na clandestinidade e no exílio. Embora também atribuam a si próprias conquistas pessoais e autoafirmações, elas se colocam no centro dos eventos públicos e descrevem suas atividades dentro dos espaços de resistência, ressaltando o êxito do desempenho. E, na maioria das vezes que julgaram não terem tido uma participação significativa, não estavam a desmerecer suas atuações políticas, mas haviam sentidos subjetivos por detrás de tais alegações.

Essas reflexões incitam a olhar para as narrativas de mulheres como memórias autobiográficas, definidas por Rago como "a noção de espaço autobiográfico, entendido a partir dos diferentes tipos de narrativas de si, entre memórias, depoimentos, entrevistas, correspondências, diários ou blogs, que permitem cartografar a própria subjetividade" (2013, p. 33). Dentro dessa perspectiva, muito mais que narrar suas vidas, essas mulheres demonstram uma preocupação com a reinvenção de si e da relação com o 
outro, dentro de perspectiva ética, a partir das noções de "escrita de si" de Michel Foucault (2006).

A despeito das considerações apresentadas até o momento, compreendemos serem importantes para constituir os sentidos da proposta do artigo, pois por mais que possa parecer inusitado para alguns(mas) tratar da história da ditadura no estado a partir da vida de uma militante, estabelecemos que as mulheres ao rememorarem seus passados políticos, o interpretam através de suas experiências e subjetividades. Portanto, a memória de Lídia permite uma outra mirada sobre a história da ditadura civil-militar no Paraná. Para refletirmos sobre a resistência da militante à ditadura e a constituição de sua subjetividade na e pela militância, a partir da sua narrativa autobiográfica, propomos estruturar a escrita em dois eixos que se entrelaçam. Primeiramente, conhecer a história de vida de Lídia, contada por ela mesma em entrevista, para que assim possamos analisar sua memória política e continuarmos na esteira da constituição de uma história possível sobre a multiplicidade de atuações de mulheres no Paraná, em tempos de ditadura.

\section{Trajetória política de uma militante paranaense}

Lídia Lucaski nasceu em 1945, em um vilarejo de zona rural chamado Tomás Coelho, no município de Araucária, no estado do Paraná. Filha de descendentes de poloneses que tinham na família um legado de luta. Em diversos momentos históricos os homens da família haviam combatido na esfera política ou nos campos de batalha por sua pátria. Seu avô materno lutou no exército polonês contra a ocupação russa, mais tarde deixou a Polônia rumo ao Brasil por não admitir pertencer às fileiras do exército russo-polonês. Do outro lado da família, seu avô paterno e tiosavôs haviam lutado na Revolução Federalista, no episódio do Cerco da Lapa. $^{4}$

4 O Cerco da Lapa foi a continuação da Revolução Federalista em solo paranaense. Começou em 26 de janeiro de 1894 e durou 26 dias. A resistência dos defensores do Cerco da Lapa desestabilizou as forças 
A infância de Lídia foi permeada pela história de vida dos grandes homens da família. Em sua casa havia sempre uma história de guerra, de levante e de revolução. Sobre esse tema, sua memória foi composta por dois sentidos: a casa de seu avô materno, que guardava inúmeros objetos que lembravam a resistência da Polônia à Russia e, de vê-lo sentado seriamente ouvindo pela rádio notícias sobre a situação política e econômica da Polônia. Outro fato que permaneceu na sua memória foi a lembrança do entusiasmo de seu pai, quando lhe contava a história de seus tios-avôs, que haviam morrido por um ideal.

Lídia mudou-se para Curitiba para cursar Filosofia na Universidade Federal do Paraná - UFPR, passou a morar na Casa do Estudante Universitário - CEU. O golpe de 1964 havia sido deflagrado, porém os desdobramentos ainda eram desconhecidos. Foi no núcleo de esquerda da CEU, como era conhecido o segundo andar, local que ficavam as meninas que contestavam a sociedade, que Lídia teve o primeiro contato com os debates sobre a ditadura. Nas reuniões cada uma apresentava as dificuldades enfrentadas, na escola, na universidade, ou seja, as novas situações que começavam a se apresentar, dado o processo de censura, perseguições e prisões.

Decepcionada com o curso de Filosofia, por considerá-lo alheio à realidade brasileira daquele momento, com professores(as) que não discutiam, nem na cadeira da disciplina de Política e Sociologia, o golpe ou o governo militar, e com acadêmicas que estavam mais preocupadas com a aparência, Lídia passou a frequentar as aulas apenas para cumprir obrigações.

Assim, a experiência acadêmica foi vivida pelos corredores, através da militância no movimento estudantil, já que Lídia identificava que essa possibilitaria a ela dar significados ao turbilhão de acontecimentos que estava vivendo. Em suas palavras, "antes do AI-5 a universidade estava distanciada, tipo numa redoma de cristal, alheia, alienada" (LUCASKI), e "como o pessoal da esquerda lia muito, então a gente lia e questionava os professores e muitas vezes eles não tinham respaldo. Então foi um certo distanciamento, a escola não correspondia ao o que na nossa maneira tinha que ser" (LUCASKI).

revolucionárias, atrasando a investida sobre São Paulo e dando tempo para que as tropas legalistas se reorganizassem militarmente (SÊGA, 2005). 
A identificação com a militância aconteceu em uma das primeiras tarefas delegadas pelo movimento estudantil. Lídia assistia a uma aula de Sociologia no anfiteatro da universidade, praticamente toda a Ciências Sociais estava lá naquele momento, um dos colegas do movimento estudantil foi até Lídia e disse que ela precisava pedir a palavra ao professor e divulgar para todos(as) que o acadêmico de medicina Issamu Itu, o "China", tinha sido preso pela polícia. Era uma tarefa nada fácil para ela, pois antes precisava vencer a sua timidez. Lídia respirou fundo e seguiu em frente: 'Aí, aquilo! Mas eu disse, 'mas eu não falo!'. A pessoa me chamou a razão, porque eu estava tão transtornada pela prisão e pela minha timidez que já era assim sabe, visceral [...] tomei de uma coragem inusitada" (LUCASKI).

Por um bem maior e por uma militância política, ela se pronunciou para mais de 70 pessoas, vencendo sua inibição em situações sociais. Qual foi o impulso da coragem de Lídia? Possivelmente a recordação do passado de luta de sua família, recordação que se tornava presente sempre que Lídia precisava superar sua personalidade tímida e seguir com o legado da família: "Se sentia um certo temor e eu lembro nesta hora do meu pai. Digo, puxa, mas os parentes, os tios, os avós, sei lá, eles perderam a vida por um ideal, lutando [...] mas eles entregaram o que era de mais precioso que eles tinham que é a vida" (LUCASKI).

Por um ideal, Lídia teve o primeiro embate com a polícia repressiva da ditadura. Dezembro de 1968, o AI-5 foi decretado. Lídia e muitos(as) estudantes estavam na sala do Diretório Central dos Estudantes - DCE da UFPR. Sabiam que a invasão do local pela polícia era questão de horas e que dali para adiante, viveriam um turbilhão de acontecimentos:

E a polícia lá, cercou, o pessoal jogava vidro em cima da polícia. Nós estávamos queimando documentos, pois tinha documentos do DCE, sabe, que tinha que ser. Aquele pânico, tanto que queimava dentro do vaso sanitário, para não dar incêndio, não tinha outra maneira, o vaso se arrebentou de tanto fogo. Uma loucura total! Eu sei que como era só uma polícia insipiente, digamos assim, a gente conseguiu sair pelos telhados, até pela casa do estudante, meio se matando, etc. [...] Foi uma coisa até hoje me emociona. Os operários, eles cortavam as barras de ferro de um metro, da construção, distribuíram para todos nós e a gente arrancando aquele petit- 
pavê das calçadas para enfrentar a polícia com a pedra, meu Deus! Ai alguém genialmente lembrou de arrancar o busto do Flávio Suplicy de Lacerda, que está lá acho até hoje. E arrastaram aquele busto, saiu no jornal (LUCASKI).

A defesa do DCE, a tomada da Reitoria da UFPR e a derrubada da estátua do ex-reitor da Universidade, foram os momentos mais marcantes do movimento estudantil do Paraná, e Lídia esteve presente em todos, lutando ao lado de homens e mulheres, já que não havia distinção de sexo nesse momento. As mulheres estiveram presentes em todos esses momentos, afirmou Lídia, e a participação delas muitas vezes foi decisiva, como a ação estratégica das estudantes de Educação Física, que fizeram antídotos para o gás lacrimogênio que seriam jogados pela polícia no momento da tomada da Reitoria da UFPR.

Desse embate aos demais, Lídia não parou mais sua militância política. Muito pelo contrário, considerava-se especializava em algumas tarefas: "Eu era muito boa de fazer cartaz, cartaz era comigo, cartolina e pincel atômico. Isso era rápido, peguei uma prática, unha sempre assim, só sujeira" (LUCASKI). E assim, à parte de fazer e rodar manifestos em mimeógrafos, confeccionar cartazes era também sua responsabilidade, portanto, dormia tarde, o que impossibilitou ela de participar em 1968 do Congresso da União Nacional dos Estudantes - UNE, na Chácara do Alemão. "Era de manhã, começava, eu digo eu não vou. Se a Revolução começar de manhã, eu não vou, só se depois do meio dia por ali. Porque eu ia dormir três, quatro da manhã, de manhã eu estava podre" (LUCASKI), mas o motivo também era outro. Naquele momento Lídia tinha consciência de que era uma estratégia errada a realização do Congresso: "Como é que você reúne, numa chacrinha ali, não sei quantos estudantes. Será que o povo não vê, olha que estrategistas que foram. Era pedir para ir para a cadeia mesmo. A situação estava difícil." (LUCASKI).

Depois disso, em 1968, saiu sua prisão preventiva, pela $5^{\text {a }}$ Região Militar, $5^{\mathrm{a}}$ Distrito Naval e $5^{\mathrm{a}}$ Zona Aérea, de Curitiba. Lídia foi denunciada pela Justiça Militar, nos artigos 23, 36 e 38, II do Decreto Lei $\mathrm{n}^{\circ} 314 / 67$, por participar e/ou promover atividades consideradas, pela acusação, como atentatórias à segurança do Estado. Na Sentença, Processo 
$\mathrm{n}^{\circ}$ 494, Lídia foi condenada especificamente por "utilizações de panfletos referentes à reuniões". 5 Sua prisão preventiva foi reflexo das medidas tomadas pela Polícia Militar do Estado, depois do episódio da Chácara do Alemão, quando 42 estudantes foram presos(as) e 15 foram processados(as), julgados(as) e condenados(as) à prisão.

A única saída era a clandestinidade. Sua vida foi revirada e constantemente era procurada em Araucária. O Serviço de Nacional de Informações - SNI vivia em sua casa, procurando informações, indícios de seu paradeiro. No CEU, seus pertences foram apreendidos e, mais tarde, o seu casaco favorito, comprado com a bolsa de pesquisa de estudante, foi visto com uma policial, e seus livros de antropologia, que tanto tinha trabalhado para comprar, "eles levaram, mas isso eu deduzo que vai ser para segurar a porta para não bater com o vento, porque tira que saiba ler é difícil" (LUCASKI).

De aparelho a aparelho, Lídia era acolhida e ajudada por amigos(as), estudantes solidários(as), parentes, mas o medo era constante, tanto de ser descoberta como de envolver as pessoas que naquele momento a ajudavam. Percebendo que o cerco estava se fechando, a militante decidiu sair do estado e seguiu, com a ajuda de algumas pessoas ligadas ao movimento estudantil, para o Rio de Janeiro. A proposta era tentar uma nova vida com o codinome Marlene e, assim, primeiramente, Lídia se escondeu por alguns meses em um aparelho sem água e luz, perto de uma favela.

Depois começou a trabalhar temporariamente como pesquisadora de produtos farmacêuticos em Copacabana, Leblon e Ipanema. Foi escolhida para essa região pela coordenadora da pesquisa, por ser branca, loira de olhos azuis, características que facilitariam a sua aceitação entre as luxuosas clínicas médicas, mas, por outro lado, Lídia aproveitava para se misturar ao meio de muitos turistas e transitava despercebida. Trabalhou muito, precisava de dinheiro, mas na hora de receber o pagamento Lídia se deu conta de que não tinha documentos para a retirada do cheque, já que, no Rio de Janeiro, ela era Marlene e não Lídia: "Aí veio no nome meu, Marlene não sei das quantas lá. Eu nunca recebi esse cheque. Essa pessoa não existia. Eu digo, nossa, eu uma pessoa que queria participar da 
revolução e faço, e cometo um erro desses" (LUCASKI). Um momento difícil de viver e de recordar também. A clandestinidade pregava peças!

Lídia, a cada dia encontrava novas complicações. Já havia se passado um ano e o Rio de Janeiro não era mais seguro. Muitos(as) estudantes, políticos(as), advogados(as) e simpatizantes foram presos(as) e, nas torturas, delataram muitas informações. Por outro lado, por nunca ter se filiado a nenhum partido ou entrado para a luta armada, Lídia teve dificuldades em encontrar grupos ou pessoas que a ajudassem. Vivia sozinha, com poucas peças de roupa, sem saber ao certo como seria seu dia seguinte. Insegura, resolveu aceitar a recomendação do Partido Comunista Brasileiro - PCB, e seguir para o exílio.

Chegando ao Uruguai, foi recebida por(pelas) brasileiros(as), mas não era seguro ficar muito tempo por lá e, em poucos dias, seguiu para o Chile, obtendo asilo político. A experiência dos acontecimentos no contexto que antecederam o golpe militar no Brasil permitiu que Lídia visualizasse que o Chile também estava à beira de um golpe militar, que derrubaria o presidente chileno Salvador Allende. Lídia fugiu antes do golpe para a Bolívia. Os golpes militares se instauravam na América Latina e, em 21 de agosto de 1971, o presidente Juan José Torres também foi derrubado por um golpe militar na Bolívia, e Lídia precisou fugir mais uma vez. Exilou-se no Peru, por lá estudou Antropologia na Universidade de Lima, definida por ela, como uma das experiências mais ricas no exílio.

\section{Narrativas de si: os enfrentamentos do passado no presente de Lidia}

A impossibilidade de narrar a própria existência acompanhou Lídia por muito tempo, pois não era fácil para ela recordar a experiência da militância durante os anos da universidade. Mesmo assim, Lídia aceitou colaborar com a pesquisa. No dia em que nos conhecemos ela parecia estar muito nervosa, mas determinada a falar sobre o seu passado, por mais que isso pudesse lhe trazer recordações e diversos sentimentos. Diz ela: 
Em primeiro lugar eu me sinto assim muito honrada que você me chamou para esta entrevista. Não sei se vai ser de grande valia, mas, enfim, o critério foi seu. E eu posso dizer, assim do fundo do coração, que hoje eu já posso falar e, digamos, quase tudo. Porque eu passei anos e acho que isso se deu com muitas pessoas que viviam um silêncio assim sepulcral. O medo era tanto que esse medo era recorrente até em sonhos, sonhos ou pesadelos. Sonhos não, porque o sonho é bom. E eu tinha muita dificuldade de rememorar isso aí. [...] Eu sempre duvidava um pouco de análise, de psicanalista [...], mas não, me libertou muita coisa, como esse fato de falar da repressão. Eu passei anos, Carla, eu não falava. Eu evitava de encontrar os amigos da época, porque, não por medo, mas era sempre o mesmo assunto, sabe, sempre o mesmo assunto. Então aquilo voltava o pesadelo (LUCASKI, grifo nosso).

A vida de Lídia tinha uma lacuna, pois ela se negava a falar sobre os anos vividos durante a ditadura civil-militar. Era a forma encontrada para se relacionar com essa parte de sua história. $\mathrm{Na}$ entrevista, não mencionou o motivo que a fez decidir pela ajuda da psicanálise. Somente considerou que, apesar de ser descrente dos métodos dessa área, foi a terapia que lhe permitiu encontrar uma forma de acessar as memórias do que ela definiu de pesadelo. Assim, Lídia já estava em um processo de memorização e talvez por isso tenha aceitado colaborar com a pesquisa. Possivelmente para ela a linguagem era um modo de dar conta do trauma. Todavia, agora ela não falava com uma psicanalista, e sim, uma historiadora. Mas, a distinção de quem estava a ouvir tinha alguma diferença para Lídia?

$\mathrm{Na}$ autobiografia, a militante pouco falou propriamente de si mesma, apenas se apresentou como uma mulher de personalidade muito tímida, devido a uma educação recatada. A representação sobre si, construída por ela, foi apreendida na análise das passagens narradas, pois, ao falar sobre os episódios, Lídia deixou transparecer seus sentimentos, suas atitudes e seus comportamentos.

Eu era a mais folclórica, eu me caracterizaria assim, eu atuava e eu era amiga de todo mundo. Como eu não tinha um partido, 
não tinha uma direção política e ideológica, naquele rumo então não podia sair [para a clandestinidade e exílio]. Porque naquele tempo tinha os sectarismos também. [...] eu queria ser livre até de partido. A minha ânsia de liberdade era tão grande que eu queria ser livre até de partido, para mim já é uma amarra. Sabia das filiações, mas não entrava, digamos, nestes detalhes particulares. A solidariedade de você fazer uma coisa para um, para outro. Claro que dentro do seu conceito de que era assim que tem que ser, fazer o que era correto, então ajuda um. Tanto que depois eu tive todo esse auxílio que eu não sei de quem era. (LUCASKI).

Sobre sua militância política, Lídia a definiu a partir de dois sentidos subjetivos bem marcados. Primeiro, a definição de que a sua militância foi um projeto pessoal atrelado às histórias de coragem dos homens da família, um legado que "nunca mais saiu da [sua] memória" (LUCASKI). Em 1964 ela entrou na universidade e, quase que naturalmente, começou a participar do movimento estudantil, talvez por considerar que, no seu tempo, deveria também fazer algo pelo país e seguir assim com o legado da família. Outro elemento a se evidenciar foi a importância que Lídia deu a sua liberdade, no que tange ao vínculo a partidos políticos ou a alguma organização de esquerda, entendendo que o poder de decisão sobre suas ações políticas deveria ser seu, pois o desejo de ajudar alguém estaria relacionado ao contexto vivido, relações de companheirismo, amizade e de solidariedade que se estabelecem na luta e não por determinações de uma organização.

Descrevendo detalhadamente sua experiência pessoal no que diz respeito ao contexto das prisões, podemos perceber como a militante reviveu - mas também denunciou - as cenas de humilhação e de violência às quais os agentes da Delegacia de Ordem Política e Social - DOPS a submeteram. Propomos dividir o contexto da primeira prisão em dois momentos, primeiro a descrição do perfil e do comportamento repressor dos agentes da DOPS, bem como dos espaços dentro desse local e, na sequência, a postura da militante nos interrogatórios. Tal divisão auxiliará na evidência dos detalhes narrados e também atenderá a um pedido feito durante a entrevista, apresentar em nossa escrita, os interrogatórios. Todavia, estruturar a análise dessa forma será também importante para que possamos perceber as motivações da fala da narradora. De fato, um aspecto 
se delineou desde o início da narrativa, o seu ressentimento - não somente em relação aos agentes da DOPS -, mas ao que veio a acontecer em sua vida, como desdobramento, não da sua opção pela militância, mas das truculências de um governo autoritário e repressor.

Lídia foi presa diversas vezes. Na primeira ela estava na CEU, foi levada para a DOPS e interrogada pelo delegado Ozias Algauer ${ }^{6}$, a quem ela desejou que estivesse hoje "morto no fundo do inferno. Não, eu não posso ser cínica hoje. Se tiver alguém que perdoe, que perdoe, eu não perdoo. Entende, me arrancaram lá da Casa da Estudante, não só a mim, que depois levaram outras pessoas" (LUCASKI). Através da memória, Lídia retornou ao dia de sua prisão. Ela estava novamente na DOPS, na Rua João Negrão. Diz ela:

Eu ficava sentada em uma cadeira de pau, até hoje tenho esse problema, aquelas cadeiras retinhas de pau bem antigas, uma sala assim, murrienta [sic], suja mesmo, não é suja de lixo, é encardida. Aliás, como todos eles eram encardidos mesmo. Encardido, gente asquerosa. Aquela tiragem do DOPS era uma coisa assim, sabe uma excrescência da humanidade. Eles, em quatro, cinco, eles saiam, entravam. Ali na João Negrão, lembro que tinha uma escadaria enorme, muquiferenta [sic] sabe, deprimente mesmo, se eu fosse da polícia tinha vergonha de trabalhar em um lugar podre daqueles. Enfim, várias vezes eles me detiveram. Só deixa eu te contar como era o ambiente lá. Então, duas ou três, quatro pessoas perguntavam ao mesmo tempo, era um horror porque perguntavam berrando, não perguntavam assim, escuta tal coisa você conhece. Não era assim, aqui só vem inocente e murro na mesa. Era para demonstrar que eles eram os machões assim, sabe, aquilo eu achava muito ridículo, eu só não entendia na época, claro, com a idade que eu tinha, nunca tinha sido presa antes, como eles não eram didáticos. Veja a inocência! Você tem que perguntar uma coisa para uma pessoa e esperar que te responda. Se está

6 Ozias Algauer foi considerado o braço direito da ditadura no Paraná, citado, pelo grupo "Tortura: Nunca Mais', como um dos torturadores da ditadura no Estado. Conforme o site Documentos Revelados, a DOPS, sob o comando de Ozias - 1969 a 1978 -, em dois anos, investigou centenas de pessoas e instituições paranaenses. Uma das operações chefiadas por Ozias foi a Operação Marumbi, realizada em 1975, que investigou e prendeu pessoas acusadas de rearticularem o PCB no estado (BRUNELO, 2012). 
falando a verdade ou não, mas há resposta. Mas isso aí depois me explicaram que era justamente para quebrar o moral. Todo mundo berrava ao mesmo tempo, a tua cabeça ficava muito ruim, aí você tinha sede, tinha fome, fome não tanto, mais sede e eles não te davam nada. Eu não tinha coragem de pedir um copo de água, sabe. E todo mundo falando, falando, falando, daí me mudaram de sala, tinha uma cadeira, tudo era muito rústico, muito ruim e a cadeira tinha dois braços finos, eu sentada ali e um aqui outro aqui, eles andavam, eles eram muito tumultuados, tudo. Só que era justamente para ser assim, era o método deles, eles tinham um método dos mais terríveis. Eu me lembro que um desses agentes, tiras, era um gordo, muito gordo, barrigudo, me parecia que ele era sujo, chegava a cheirar mal, sabe, um cabelo todo gosmento, ele fumava um charuto e sentou nesse braço aqui esquerdo e ele se encostava em mim, eu não tinha mais para onde ir porque aqui tinha o outro braço. $\mathrm{E}$ daí disse: 'colabora, colabora, riquinha'. Como se eu fosse rica, eu disse 'não sou rica'. Talvez pelo meu aspecto, loira de olho azul, pode ser. Talvez, se eu fosse negra, ia ser pobre, mesmo que fosse dona de um banco. Eu acho assim um pouco por isso. Acho que ali tinha um certo complexo até de cor, sabe. Riquinha, está na faculdade e tal, sabe, assim, até o tom de voz (LUCASKI, grifos nossos).

Lídia parecia relembrar, com certa precisão, aquele episódio. Se, por muitos anos, ela se negou a falar sobre o assunto, quando se permitiu, suas memórias receberam voz e se expandiram, trazendo informações e impressões sobre o vivido. Assim, por mais que o trecho citado seja longo, ele é significativo para percebermos como a militante agregou a essa memória algumas nuances. Para Lídia, as recordações sobre suas experiências na ditadura se assemelharam a pesadelos e o episódio narrado é uma amostra de como ela reviveu tais experiências. A memória traumática materializou-se pela linguagem e recebeu contornos de penumbra e de peculiaridades repulsivas, abrangendo o local e os agentes do DOPS. O local foi retratado como um lugar imundo e deprimente e a imundície não estava atrelada ao lixo ou à falta de limpeza, mas às ações que aconteciam naquele lugar, à violação dos direitos humanos, à tortura, à repressão, ou seja, as paredes estavam impregnadas das atitudes sórdidas dos agentes. A imundície também era a característica daquela 
"excrescência da humanidade" (LUCASKI). A representação que a militante fez do agente que a aconselhou a colaborar é a caricatura cinematográfica de um legítimo torturador.

Lídia usou duas palavras, murrienta e muquiferenta, que não encontramos nos dicionários da língua portuguesa. Possivelmente são palavras do seu próprio vocabulário ou então inventadas na ocasião da entrevista, para dimensionar o quanto era repugnante a política institucional de repressão e tortura da ditadura. Conforme Leonor Arfuch, os testemunhos traumáticos requerem quase que obrigatoriamente imaginação, não é fácil trazer ao presente cenas que são difíceis somente de imaginar, então como narrar? Para a autora, o processo de "remplazar las manifestaciones a través de las cuales el inconsciente inicialmente 'habla' (flashbacks, pesadillas, desbordes emocionales), por un lenguaje consciente que intentará hablar una y otra vez de aquello que no puede ser dicho" (ARFUCH, 2012, p. 50), é a relação ambivalente entre "la posibilidad y la imposibilidad del lenguaje para dar cuenta del trauma" (Ibidem, p. 50). O trauma, por vezes, tem uma extensão que não encontra na linguagem possibilidades de se figurar, embora, ao mesmo tempo, ele necessita da linguagem para a sua possível superação. Talvez por isso Lídia tenha precisado inventar tais palavras, pois não existiriam palavras nos dicionários que pudessem dar conta de ilustrar o que ela narrava.

No fragmento do relato grifamos algumas expressões de Lídia para que pudéssemos evidenciar que, ao mesmo tempo em que ela rememorava aquele episódio, expunha também sua conduta frente às atitudes ameaçadoras dos agentes. A militante, no momento do interrogatório, achou os agentes nada didáticos, uma vez que não conseguiu responder a nenhuma das perguntas, pois todos falaram ao mesmo tempo, não permitindo que ela se manifestasse. Ora, se era um interrogatório, entre respostas verdadeiras ou falsas, pelo menos ela precisava falar, naquele momento, ela era a subversiva. Lídia, naquela ocasião, considerou os agentes ignorantes, porque não era assim que um interrogatório deveria proceder. No presente, refletindo sobre sua conduta, ela riu de sua ingenuidade por não saber que aquela atitude, nada didática, era uma estratégia. Outro ponto destacado foi a resposta da militante ao agente que cheirava mal e tinha cabelo gosmento. Prontamente ela lhe respondeu que não era rica. Sua indignação em ser considerada "riquinha" por ser branca de olhos azuis era uma ofensa, primeiro porque ela veio de uma família de trabalhadores(as), foi emancipada por seu pai na adolescência para que ela 
pudesse trabalhar e, depois, pelo preconceito racial do agente, ou seja, para a militante ele foi duplamente preconceituoso. Lídia não tinha coragem de pedir um copo de água, tamanha era a barbárie do interrogatório, mas não se calou com a insinuação do agente e, talvez, para a ela a motivação de sua resposta não estava na coragem, mas, sim, na sua indignação.

Daí interrogatório e tal. Conhece Vitório Sorotiuk? Digo, conheço. Quem é ele? Digo, o presidente do CAHS, presidente do DCE na época. Nossa, deu uns murros na mesa, isso eles sabiam, eles queriam saber quem ele era de outra forma, político, comunista, subversivo, terrorista, o cão, né, claro. Não tinha nada que dizer isso, sabia que ele era o presidente do diretório e fim de papo. Só que hoje eu falo isso assim, só que lá dentro acho que eles estavam em cinco ou seis. Então, conhece fulano, conhece, jogavam umas fotos. Quem que é esse? Esse eu nunca vi, não sei. Não adianta. Aquela covardia, Carla! Eu fico irada com aquela covardia. Porque eu, estudante, sozinha, advogado nem pensar, querida! Me deixaram umas quatro a seis horas em uma sala e a porta estava aberta, eu andei por ali, tinha uma cadeira assim, só, nada. Não entrava ninguém, não saia, eu fui tentar a porta assim, sem chave e digo, eu vou embora daqui, só que mandaram eu ficar lá. Eu digo, eu vou embora. Eu disse para mim, eu vou embora, não vou ficar aqui mais. Isso foi outro ardil assim, sei lá, artifício, eles faziam para que a pessoa saísse. Eu digo "não interessa", e lá dentro eu ouvia grito, como se alguém estivesse apanhando. Sendo espancado, torturado, grito, grito. Disse, não vou ficar aqui, não vou. Vinha o pânico, a sede, a fome com o cansaço, assim, ai eu sai, fui para a Casa da Estudante. Olha a inteligência! Eu pensei ainda comigo, veja bem, eu não estou presa, porque se eles me deixam numa sala horas, e horas e horas, não podia ir no banheiro, nem sabia, nem pedia. Então eu não estou presa, porque tem uma porta fechada, mas não com a chave, então não estou presa e ai foi o meu erro. Quer dizer, me induziram a isso (LUCASKI grifos nossos).

Em menos de 10 minutos a viatura da DOPS estava novamente no CEU a sua procura. Podemos perceber, pelo fragmento, que a decisão de ir embora da DOPS foi sua - ela sabia que o interrogatório não havia 
terminado, pois mandaram que ela permanecesse naquela sala -, porém o fato de estar sozinha, a sala aberta e, suspeitando que pudesse ser a próxima vítima a ser torturada, resolveu sair. Embora, em instantes ela havia questionado o delegado sobre sua condição na DOPS, ela estava presa ou detida? E ambos os casos ela tinha o direito de ser acompanhada por um(a) advogado(a):

Eu perguntei se eu estava presa, o delegado deu um murro na mesa e disse: 'Não, você está detida!' Eu digo: Qual é a diferença de estar detida doutor - com a vozinha mais suave do mundo -, e estar presa?' 'Não, você está aqui só para o interrogatório', disse: 'Então eu posso sair também. Se eu não estou presa, eu posso sair'. 'Não pode!' 'Então estou presa'. Olha a discussão! Aquilo começou irritar, aí eles me achavam riquinha, metida. Mas não era, era um direito meu que eu queria exercitar. Então eu não achava justo que ninguém estivesse ali sem o mínimo, era uma afronta a tudo que tinha de normalidade, mas isso é uma besteira que passou na minha cabeça que ali quem tinha um trinta e oito na cinta e um cassetete, pronto, era a lei (LUCASKI grifo nosso).

A narradora, ao reconstruir o momento do interrogatório, por diversas vezes avaliou o seu comportamento, deixando perceptível sua surpresa com sua inocência ou falta de inteligência naquela época. Lídia entendia que a decisão de fugir da DOPS e retornar ao CEU foi induzida pelos agentes para intimidá-la a cooperar com as informações desejadas, pois, quando a perguntavam se conhecia alguns(mas) dos(as) militantes que eles citavam, ela respondia que sim, afetando uma tranquilidade forçada. Era impossível não os(as) conhecer, independentemente de se ela fosse ou não militante, uma vez que eram estudantes conhecidos(as) por todos na universidade. Identificou ainda que foi descabido seu duelo verbal com o delegado, sobre a diferença entre estar detida e/ou presa. Isso era o que menos importava, a lei que imperava era a do mais forte e o legalismo era somente de sua parte. Assim, portanto, no momento em que a narradora reviveu tais experiências, parece-nos que ela não identificou que sua postura e seus questionamentos foram estratégias de enfrentamento, ou 
seja, a militante não reconheceu na sua conduta uma forma consciente de resistência.

Não temos o objetivo de atribuir valores como coragem, inteligência e heroísmo à narradora, porém não podemos deixar de considerar que os enfrentamentos de Lídia ao poder instituído foram diversos e, portanto, se enquadram na nossa concepção de que foram múltiplas as formas de resistência dos sujeitos durante a ditadura civilmilitar, entre elas, salvaguardar a vida e denunciar/questionar as arbitrariedades do governo autoritário, seja em assembleias, nas ruas e até mesmo dentro dos próprios espaços da repressão. Passamos a mais uma parte narrada sobre o interrogatório que demonstra como Lídia soube criar enfrentamentos como forma de resistências, mas sua personalidade tímida, principalmente o medo de se expressar em público, devido à educação familiar conservadora e rígida, parece se diluir e desaparecer nesse episódio. Diz ela:

eles foram perguntando várias coisas, muita gente berrando, a minha cabeça está muito confusa assim e até que eles arrancaram... era escrita a máquina ainda, não sei quanto papel carbono, tiraram as folhas e sem carbono me deram para que eu assinasse a primeira via, só que eu não sei quantas folhas tinha antes. Quantas vezes o delegado, outros me interrogavam e eu estava pensando o que eu vou dizer assim e o escrivão continuava escrevendo. Aí eu notei aquilo, aí eu digo, espera aí, eu não estou falando nada, o que ele está escrevendo? Daí eu no silêncio e o cara escrevendo. Eles me deram para assinar a última folha. Dizia assim: nada mais foi dito, nada mais foi perguntado. Pronto e o meu nome, tipo duas linhas. Daí eu disse para o delegado, chamei de doutor ainda, aquela excrescência. Eu digo: 'Doutor, mas eu gostaria de ler o meu depoimento, aqui só está duas linhas e a minha assinatura'. As últimas duas linhas não diziam nada, meu Deus, o que será que eles me escreveram. Ele deu um murro na mesa, aí vem a loucura do berro e da ameaça, sabe. Ele disse assim: 'Está chamando o sujeito de desonesto. Isso aqui é uma delegacia, aqui ninguém é desonesto'. Digo: 'Não, eu não disse isso, não estou questionando a honestidade, a honradez de ninguém. Eu só gostaria de ler o que eu declarei. Acho que é um direito que eu tenho'. Nossa! Esse homem ficou louco e todos eles. Bom, aí a 
minha estupidez foi tanta que, quando eu fui assinar, eu pus embaixo do meu nome, estava meu nome escrito, eu pus sob coerção. Peguei com a mão, assim pus Lídia Lucaski, assinei, sob coerção. Carla de Deus! Foi o maior erro da minha vida, mas não tinha advogado, quer dizer, a ilegalidade era tanta, flagrante, uma afronta a tudo. O delegado e aquele patife que estava lá, ele rasgou aquele documento, a última folha, lá para a frente não sei o que tinha. Naquela hora, quem tem o mínimo de juízo não vai, daí ele pediu ao escrivão e o escrivão bateu aquela porcaria novamente. Agora assine direito. 'Assine direito' era sem o 'sob coerção'. Ai já comecei tomar um pouco de juízo e assinei, meu nome (LUCASKI, grifos nossos).

Assinar o documento de seu interrogatório com a expressão "sob coerção" foi uma forma de Lídia se proteger, pois ela não sabia o que o escrivão havia registrado naquele documento. Possivelmente eram informações que foram inventadas e atribuídas a ela, como uma delatora de companheiros(as), enfim, a militante somente sabia que aquele documento poderia conter inúmeras informações, menos o que ela havia realmente declarado. Esse episódio permaneceu por muito tempo na memória de Lídia. Ela poderia ter sido usada para fins específicos e jamais teria a chance de contar a verdade. A narradora temia por um "julgamento histórico que alguém fosse fazer porque eu não sei o que é que tinha: 'Carla! Como é que você assina um documento praticamente em branco? Eles podiam escrever o que eles bem entendessem!" (LUCASKI).

Nos arquivos da DOPS, na pasta individual da militante, encontramos esse documento, denominado Ato de Declaração ${ }^{7}$, produzido em 15 de janeiro de 1969. Inicialmente, o documento trouxe referências sobre a Lídia, como idade, local em que nasceu, filiação, profissão e endereço. Informou ainda que, no momento do interrogatório, estavam presentes o escrivão, o delegado Ozias Algauer e a depoente. O documento encontrado tinha apenas uma página e parecia ser composto por duas, já que na primeira o escrivão finalizou o documento citando as assinaturas

7 Ato de Declaração. Documentos/Informações referentes à Lídia Lucaski. Nº 02545 . Acervo da DOPS . Disponível no Arquivo Público do Paraná. 
que se seguiam na próxima página, portanto, fato que corrobora o relato da militante, que disse ter assinado uma página em branco. $\mathrm{O}$ teor do documento é descritivo, informou que Lídia teve conhecimento da assembleia do DCE da UFPR no Diretório Acadêmico Nilo Cairo, compareceu ao local, mas a assembleia não ocorreu. Informou que ela fazia algumas visitas à prisão para levar jornais, roupas e comida a 15 estudantes detidos(as) - não foi mencionado quem eram os(as) estudantes e qual o motivo da prisão - e, ainda, citou as disciplinas da universidade em que ela havia reprovado. As informações contidas no Ato de Declaração são corriqueiras e não houve muito a registrar, pois, apesar de ter sido o primeiro depoimento prestado por Lídia, ela havia conseguido proteger as informações do movimento estudantil. Portanto, a DOPS apenas registrou algumas notas e, como precisava preencher o documento e de alguma forma depreciar a militante, informou que ela não era uma boa aluna dado o seu histórico acadêmico. Por fim, o escrivão finalizou: "Nada mais disse nem the foi perguntado. Lido e achado conforme, vai devidamente assinado" - sabemos, porém, que Lídia assinou, mas não leu o depoimento.

Como já foi apontado, ao relatar o episódio do interrogatório, Lídia avaliou seu comportamento no passado. Se, naquele momento, ela entendia que deveria agir daquela forma, no presente sua militância foi questionada por ela mesma, por vezes, se surpreendeu com a inocência de suas atitudes. Caracterizar de inocente sua atuação parece estar atrelada à identificação, por parte da militante no presente, das estratégias empreendidas pelos agentes da DOPS durante o interrogatório. Nesse sentido, Lídia entende que, naquele momento, suas atitudes não foram decisões suas, que ela foi induzida a tomá-las. Embora a narradora tenha demonstrado que reconheceu muitas das estratégias dos agentes, parece-nos que ela não identificou que registrar informações, mesmo nos momentos em que ela se negou a responder, seria, supostamente, uma das estratégias dos interrogadores para intimidá-la. Levantamos essa hipótese por entendermos que essa lembrança a acompanhou por muito tempo, ou seja, o temor que alguém um dia a julgasse. Não era temor por ter assinado sem ler - pois, quanto a isso, ela até tentou fazer algo -, mas que o documento informasse,

8 Ato de Declaração. Documentos/Informações referentes à Lídia Lucaski. No 02545 . Acervo da DOPS. Disponível no Arquivo Público do Paraná. 
mesmo que falsamente, que ela teria delatado informações que levaram militantes a prisão, a tortura ou a morte. Esse parece ser um sentimento inalterável em sua vida, o que não permitiu que Lídia pudesse supor que tal prática fosse uma estratégia utilizada em muitos interrogatórios.

Para Lídia, a dimensão política de sua militância estava na execução das tarefas do movimento estudantil, pois ela não identificou que os enfrentamentos, durante os interrogatórios, pudessem ser uma forma de ação política. De um modo geral, o que se percebe é que, para a militante, sua capacidade política se formou nas inúmeras atividades realizadas e não na ação de enfrentar o poder instituído dos agentes da DOPS, já que esse segundo ponto foi percebido por ela apenas como uma reação espontânea à circunstância vivida. Conforme verificamos nos fragmentos acima citados, Lídia definiu sua atuação como inocente, logo não estratégica. Já em relação às tarefas desenvolvidas, a militante estabeleceu outra análise ao reconhecer que soube criar estratégias para ser bem-sucedida.

Lídia tinha uma habilidade que a diferenciava das demais militantes, ela sabia dirigir e tinha carteira de habilitação e por isso dirigia os carros usados pelo movimento estudantil. Depois do cerco ao Congresso do Alemão e da prisão de muitas lideranças, coube a ela esconder os carros da União Paranaense de Estudantes - UPE. Foi uma tarefa nada fácil, pois todos os carros da UPE tinham a logomarca da instituição e andar por Curitiba em tempos de perseguição aos(as) estudantes com um carro sinalizando que era do movimento estudantil era um risco alto.

Associado ao fato de ser uma das poucas mulheres militantes do movimento estudantil que tinham habilitação e por nunca ter se filiado a algum partido político ou organização de esquerda, Lídia entendia o seguinte: "Eu tinha, digamos, de certa forma, uma vantagem porque como eu não era filiada, todo mundo confiava qualquer coisa" (LUCASKI). Ela foi designada para uma atividade perigosa, levar até Maringá um estudante que estava doente, o qual, para ela, era uma liderança de alguma organização. Lídia e o militante "com sotaque do nordeste" (LUCASKI) seguiram para Maringá durante a noite, em um fusca emprestado de uma tia. No meio da viagem, num Posto da Polícia Rodoviária Estadual, o fusca foi parado e Lídia precisou encenar a história que veio formulando a viagem inteira, a de que ele era seu noivo e ambos estavam em uma viagem romântica. O policial conferiu os documentos do carro, a identidade dela e, ao questionar sobre o seu acompanhante, Lídia gentilmente respondeu: "Meu noivo, né, ele está dormindo. Deixa ele" (LUCASKI). A estratégia da 
militante foi usar das aulas de teatro, que frequentou na universidade, para compor uma personagem: "Parece incrível que você se modifica. Eu não sou muito eu aqui, não" (LUCASKI). Sua atuação não levantou suspeita. Eram apenas um casal de noivos em uma viagem romântica. Entretanto, atuar não era fácil: "Por dentro eu estava morta, exausta como se tivesse o mundo nas costas, que é uma coisa que até hoje me emociona" (LUCASKI). Ainda sobre esse momento, diz ela:

\begin{abstract}
Não, não precisava ir sozinha, não precisava ir para Maringá. O caso era levar essa pessoa que veio não se sabe de onde, que devia ter problema, que não sei por que ele estava com aquele colete de pescoço que não sei como é que chama. Ele tinha que sair de Curitiba, tinha que sair e tinha que ir para Maringá. Veja bem, quem me entregou era pessoa de minha extrema confiança, que eu conhecia há muito tempo. Era tipo assim, ter que salvar essa pessoa, alguém tem que ir. De ônibus não podia, de certo eram mais vigiados. Até me falaram na época que até pelo fato de motorista mulher, era melhor que motorista homem. Era o que se acreditava, mulheres podem falar mais, etc. Me disseram: 'Pinte a boca, bote brinco!'. Eu nunca tinha usado brinco. Daí passei um batom: 'Olha isso!', já me disseram e o teatro tinha já me ajudado um pouco - fazia teatro infantil (LUCASKI).
\end{abstract}

Não foi esse o único momento em que a narradora criou uma performance, reforçando as características femininas para cumprir as tarefas designadas a ela. No trecho acima percebemos a posição de Lídia. A escolha de aceitar ou não a tarefa foi sua, mesmo sabendo que seria uma viagem perigosa e não havia mais ninguém para executá-la. Mas o comprometimento com a luta, a necessidade de salvar uma vida e de ser fiel ao indivíduo de sua extrema confiança foram sentimentos mais fortes que o medo. Lídia tinha uma missão, levar o militante até Maringá. O planejamento e a execução da tarefa eram sua responsabilidade. Assim, Lídia emprestou o carro de uma tia, inventou uma história convincente para o caso de que fosse parada em algum bloqueio policial e criou uma personagem completamente diferente dela mesma. De militante do movimento estudantil, Lídia passou a interpretar o papel de uma mulher 
que estava noiva, com uma boa aparência, no que diz respeito à maquiagem e adornos, e completamente alienada em relação à política.

Em 1969, clandestina no Rio de Janeiro, às vésperas de sair do Brasil via Uruguai para o Chile, Lídia conheceu Branca Moreira Alves ${ }^{9}$, que a convidou para um almoço em sua casa, para a ajudar com os preparativos finais da viagem. Lídia tinha apenas um vestido: "Ela dizia: 'Você não pode ir com esses trajes, você é muito, está muito estudante, você tem que ficar assim, sabe, você é loira de olho azul, barambararam. Você vai sair daqui, mas você vai ser bem diferente. Ninguém vai te reconhecer!"” (LUCASKI). Assim Branca foi sua modista: "Brinco, bijuteria tipo fina, tinha que pôr brinco de argola, não tinha nem orelha furada, eu tinha que parecer muito bonita, deixar a unha crescer, fazer a unha, pintar o cabelo de uma cor bem escura, echarpes de seda" (LUCASKI). E, por fim, a última recomendação: Lídia precisava se passar por uma mulher fútil, usar das técnicas do teatro e representar o papel de sua vida, embora isso, para Lídia, não era somente atuar como se estivesse em uma peça de teatro, "mas acho que vai acumulando tanto que eu não consigo introjetar esse personagem novo. Que daí é teu problema mesmo, você não está simplesmente representando, é bem interessante" (LUCASKI). A militante se referia ao sentimento de sair do seu país, de todas as dificuldades vividas durante a clandestinidade, entre elas a incomunicabilidade com a família e, naquele momento, como num passe de mágica, deixar tudo isso de lado e teatralizar o papel, conforme Lídia, de uma madame:

Eu tinha umas unhas parecia do Zé do Caixão de compridas, pintadas de vermelho. Naquele tempo se pitava em ônibus, me compraram uma piteira. Aí eu coloquei um brinco de esmagar a orelha, porque eu não tinha orelha furada. Aquilo me amortecia a orelha, de vez em quando tirava, parecia aquelas que os escravos usavam, aquelas argolas, como chama, os grilhões. A minha orelha amortecida e eu sempre fingindo que estava dormindo. Tipo cílio - se eu chorasse, aquilo eu ficava com a cara de uma, nossa! Era o teatro do absurdo. Aí, note bem, eu

9 Branca Moreira Alves, feminista, advogada e autora de diversos livros sobre o feminismo. Durante a ditadura civil-militar ela se exilou nos Estados Unidos, onde criou um grupo de reflexão sobre o feminismo. 
fingindo que estava dormindo e tudo, podia, um monte de gente fumava no ônibus, eu tinha que dar uma de madame. Aí me deram um monte de revistas. As revistas eram tipo assim, Contigo, Amor, eu não sei (LUCASKI grifos nossos).

O teatro do absurdo para a militante não era ter que passar por tudo aquilo para não ser reconhecida, mas ter que se vestir e se comportar como uma madame. Isso, aparentemente, era algo muito difícil para ela, não somente porque não estava acostumada a se vestir assim, a cuidar de sua aparência daquela forma, até mesmo porque não foi essa sua educação familiar. $\mathrm{Na}$ universidade tinha asco das estudantes com seus trajes da moda e salto alto, ou seja, as consideradas alienadas em todos os sentidos. Assim, tudo o que ela não queria para si, naquele momento, ela precisou ser, a identidade feminina aceita naquela sociedade repressora. Lídia viajava do Rio de Janeiro para Porto Alegre. Em São Paulo o ônibus foi interceptado pelo Exército e os(as) passageiros(as) obrigados(as) a apresentar as carteiras de identidade e Lídia não tinha nenhum documento com ela:

E daí acordei assim, eu não estava dormindo, nada. Eu não dormi do Rio de Janeiro até Porto Alegre, mas sempre estava com sono, tem que fazer o gênero da coisa, bocejando, abrindo documento, documento, todo mundo. Digo: 'Meu Deus! Como é que eu vou sair daqui toda maquiada para o camburão.' Pensei, sabe, peguei aquelas revistas assim, que eu tinha, Cláudia, não lembro o nome, fiquei olhando, dessas bem de futilidades, com aquelas unhas. Eles acenderam todas aquelas luzes. O motorista foi obrigado a acender, uns dormindo e tal. De todos os homens, ali que está uma vantagem, quase todos os homens, eu não sei os muito de muita idade não tinha que dar documento, que não estava na mão, alguns eles pegavam um ou outro e tal. Chegou um e não sei de onde que eu disse: 'Oi, tudo bem?' Para dizer 'Oi, tudo bem!' tinha que ser uma débil mental. Não podia ter alguma coisa na cabeça. O cara cheio de metralhadora, umas curtinhas. Eu era nova na época, ele soldado, cabo: 'Oi, tudo bem?'. 'Oi. Bom, tudo certo aqui, boa viagem, obrigado. Boa viagem!' (LUCASKI, grifo nosso). 
Lídia soube instrumentalizar o gênero ao seu favor, pois estrategicamente reforçou as características do feminino tradicional e construiu uma personagem que pudesse ludibriar a repressão. A madame que ela teatralizava tinha também uma performance em se comportar, com expressões faciais, gestos e olhares, enfim, um conjunto de técnicas que compunham a sua atuação. No momento em que o soldado do Exército solicitava a carteira de identidade dos(as) passageiros(as), Lídia reforçou ainda mais essas técnicas e agregou uma a mais, a sedução, pois o soldado deveria prestar atenção nela e não no fato de não ter o documento em mãos. Assim, antes mesmo de o soldado dirigir a palavra à Lídia, ela iniciou uma conversa, perguntando se ele estava bem. Podemos supor que a militante, com seu batom vermelho, tinha um largo sorriso nos lábios. Durante todo aquele momento, o medo de ser presa pela falta dos documentos era imenso, mas o que passava pela mente da militante foi: "Meu Deus! Como é que eu vou sair daqui toda maquiada para o camburão" (LUCASKI), evidenciando que, para a narradora, mesmo tendo usado conscientemente a estratégia de compor uma personagem, aquela personagem era muito difícil de interpretar, pois se sentia indignada por precisar se passar por uma mulher descomprometida, pertencente a uma parcela da sociedade brasileira que foi adepta e incentivadora da ditadura civil-militar, para poder fugir do país e continuar viva.

Aquela foi uma viagem difícil. Não era a Lídia quem viajava, e sim uma mulher preocupada somente com as notícias da Revista Cláudia, mas passar a poucos quilômetros de sua casa, da família, que pensava que ela estava morta, isso fez Lídia chorar sem se importar que sua maquiagem fosse borrar - essa coisa estranha que ela nunca tinha usado na vida. Sua família não poderia saber sobre seu paradeiro e isso era um perigo que ela não queria correr. Estava sozinha e a viagem do Rio de Janeiro para Porto Alegre foi uma angústia sem fim. Estar tão perto de sua casa e não poder retornar e ser a Lídia novamente foi narrado com muita tristeza e choro. O

sentimento foi revivido, eram as marcas que a militante mencionou no início de sua entrevista, eram esses os momentos que não permitiam que ela falasse sobre esse período de sua vida, a dificuldade em narrar ereviver.

$\mathrm{O}$ retorno a si, o cuidado de retornar à sua história de vida foi algo que precisou de muito esforço para Lídia. A militância política se iniciou logo que ela entrou na universidade e, em 1969, já estava com a prisão preventiva decretada e vivendo clandestina. Procurada pela polícia, Lídia contou com ajuda de alguns(mas) militantes do movimento estudantil e 
passou a viver em lugares escolhidos às pressas, concedidos por(elas) simpatizantes à luta dos estudantes, mas o cerco se fechava a cada dia e as dificuldades de uma vida clandestina começavam a pesar. Conforme a narradora, foi uma época difícil, incerta e angustiante. Chorando e emocionada, relembrou que "ninguém mais me aceitava, eu me sentia a própria leprosa contaminante. Porque eu não queria implicar mais ninguém, eu digo 'Tenho que arcar com isso, não sei mais o que fazer!"' (LUCASKI, grifo nosso). Com essa passagem, podemos perceber que Lídia assumiu, no passado, que a responsabilidade das adversidades que se apresentavam deveria ser sua, uma posição que também incorporou no momento da narrativa. Mas, a militante deveria arcar com as consequências de ter escolhido a militância política? Julgou ter se enveredado por um caminho que somente trouxe infortúnios? Ter-se-ia ela arrependido?

Lídia não se arrependeu de seu passado. Analisou sua militância entre erros e acertos, valorizou sua capacidade de desenvolver as tarefas designadas a ela e, por fim, assumiu as consequências de suas escolhas. Entendemos que, para Lídia, a militância política foi uma escolha para si, a representação da sua liberdade e poder de decisão. Não havia, portanto, arrependimento por ter optado pela militância, tanto que ela assumiu sozinha as consequências dessa opção. Em busca de responder às nossas perguntas, apresentamos mais um fragmento da narrativa, o momento de decisão pelo exílio. Em suas palavras:

É meio duro se ouvir isso [precisar sair do país], porque daí por mais que você nasceu, mais que tudo, você não serve para ficar aqui, você tem que ir embora. Eu pensei: 'Putz, mas que crime que eu cometi, não? Escrevi manifestos, rodei manifestos, distribuí manifestos, sujei a mão de tinta, pichei rua, fiz a homenagem da morte do Che lá na Casa da Estudante, botamos a bandeira do Brasil com tarja preta, era coisa da época, coisa da idade, da época, e agora tem que sair do país?!'(LUCASKI).

Um sentimento bem visível surge do relato da narradora, o ressentimento. Assim, se considerarmos a forma como Lídia narrou o interrogatório, como descreveu os agentes, o desejo de morte ao delegado Ozias, a transparência dos sentimentos de ódio, de remorso e de tristeza, 
podemos afirmar que o fio condutor da narrativa foi o ressentimento do que ela viveu durante a ditadura. Para Lídia, portanto, "arcar com isso" representou assumir o estigma de não somente ter que fugir para continuar a viver, mas de ter sido perseguida como uma criminosa por distribuir alguns panfletos, já que tal ato era considerado pelos militares um crime contra o país. As atrocidades, truculências e violências cometidas pelos agentes da ditadura civil-militar, independentemente de serem conhecidas por Lídia antes de sua escolha pela militância, deveriam ser assumidas, pois ela decidiu por sua vida. Por outro lado, tal postura, no passado e no presente, pode ter sido uma das formas que a narradora encontrou para se reconciliar com o vivido.

Retornemos à pergunta lançada no início da análise da militância de Lídia. Haveria alguma distinção para ela em narrar a sua trajetória política a uma historiadora? Sim, houve. Sobre sua militância, Lídia considerou que "é bom se alguma lição restar disso, para que nunca mais aconteça. Para que a pessoa saia de casa e possa voltar sozinha, sem ser presa, torturada ou, enfim, sofrer qualquer tipo de repressão" (LUCASKI) e, em outro momento entendeu que: "acho que não se aproveitou nada [da entrevista]. Você pegou uma pessoa que fez meia dúzia de panfletos, distribuiu outra e sujou a mão. E você acha que eu sou importante e que aí é triste, né?" (LUCASKI). De uma aparente contradição, entendemos que há uma coerência compreensível nesse binarismo. No primeiro fragmento, Lídia reconheceu e reafirmou a sua escolha pela militância, uma luta legítima e que trouxe um legado histórico e conquistas para os dias de hoje. Já no segundo, ao indicar que talvez sua trajetória não fosse tão importante, Lídia não fez uma depreciação da própria militância, mas continuou a questionar como uma pessoa pode ser perseguida, presa e julgada pelos agentes da violência política da ditadura, por ter, entre outras ações, distribuído panfletos? Narrar sua história de vida a uma historiadora era uma forma de tornar visível o que os militares foram capazes de fazer aos sujeitos que pensaram diferente deles, pois foram situações-limite que ultrapassaram o absurdo.

Conforme Alessandro Portelli (1997), em uma entrevista nem sempre o(a) historiador(a) oral está em pé de igualdade com os sujeitos entrevistados. Na maioria das vezes são os(as) historiadores(as) que estão revestidos de autoridade e, "na maioria dos casos, o poder, o status e o prestígio - reais ou imaginários - oferecidos pela profissão interferem no desempenho do trabalho" (PORTELLI, 1997, p. 20). Mesmo concordando 
com o autor, no caso de Lídia foi diferente. Parece-nos que a militante compreendia que contar sua história a uma historiadora, uma profissional que tem legitimidade reconhecida para escrever sobre o passado, era uma forma de tornar visível, para o registro histórico, os nomes e os atos dos agentes da repressão. Nesse sentido, encorajada e determinada, Ligia travou uma análise do perfil de um torturador. Em suas palavras,

Eu acho, sabe, Carla, não sei se eu guardo esse rancor, essa mágoa. Um torturador deve ser uma pessoa muito anormal. Eu queria, sabe, deixa eu fazer uma entrevista com o senhor. 'Como o senhor se sentia? O que o senhor fazia?' Tipo você está me perguntando agora, eu queria ter esse direito. Eu ainda não sofri nada em comparação com os outros. Uns perderam a vida sob tortura, coisa horrorosa! Agora, veja bem, eu queria saber, agora vem esse ser, como ele é, ele é feito de carne, osso, ele é gente, assim, ou ele é um monstro, como ele tem a cara de um monstro. Carla, quem que pode pegar alguém, tem que ser anormal. Um psicopata, como é essa pessoa? Tem mulher, filho, neto, cachorro, gato. Como que é ele em casa? A gente, quando faz uma barbeiragem no trânsito, nossa, olha a sujeira que a gente fez. Dá vontade de parar e pedir desculpas, daí atrapalha mais ainda. Dá um negócio terrível, se faz até sem querer. Agora você pegar deliberadamente, friamente, gente que não te fez nada, que você não dialoga. Porque se você pensa de uma forma diferente que eu, então vamos discutir, você continua com a tua verdade e eu com a minha, e a amizade é a mesma. E agora um monstro desses. Eu queria que tivesse muito remorso. Até falei com a minha analista. E ela disse: 'Não, remorso tem você, tenho eu'. As pessoas elas são insensíveis para isso, achavam que estão cumprindo o dever tudo corretamente e recebiam para isso. É brutal, se você pensar. A minha cabeça tem coisa que é difícil de pensar, de raciocinar, digerir aquilo (LUCASKI).

A narradora citou nosso nome por duas vezes, algo que já havia feito em outras ocasiões, mas nesse momento, particularmente, tentava criar um vínculo pessoal, talvez para se sentir um pouco mais confortável com o tema polêmico e, assim, estabelecer um diálogo; para que 
raciocinássemos com ela sobre a humanidade ou sobre a barbárie de um sujeito torturador. Nesse momento compreendemos o que Roger Chartier (1996) denominou de a inveja do "historiador dos tempos consumados" ao "historiador do tempo presente", já que este último, ao ser "contemporâneo de seu objeto e portanto partilha com aqueles cuja história ele narra as mesmas categorias essenciais, as mesmas referências fundamentais" (1996, p. 216), tem a proximidade como uma aliada, por permitir um melhor entendimento da realidade estudada e a compreensão dos sujeitos históricos, cujas maneiras de sentir e de pensar ele(a) reconstrói mediante a narrativa histórica. Nesse sentido, embora exista a diferença geracional entre entrevistadora-entrevistada, pois Lídia viveu aqueles anos e nós, enquanto historiadora, somente conhecermos a época através da pesquisa, partilhávamos de diversas opiniões e de diversos sentimentos sobre a ditadura civil-militar. Entre eles, a revisão da Lei de Anistia, a abertura dos arquivos militares, a punição aos agentes e colaboradores da ditadura, reparação moral e material aos familiares dos mortos e desaparecidos e a instauração da verdade sobre a história da ditadura militar no Brasil. Assim, portanto, o tema ditadura não estava atrelado somente à história do país, pois tal período ainda se refletia, em muito, no presente da sociedade e na vida de nós duas. E por isso, além de conhecermos a historiografia sobre esse período, compreendíamos, pela oralidade, a multiplicidade de construções, de conflitos e de ressentimentos da rememoração do passado pelos sujeitos históricos. Na narrativa autobiográfica pudemos conhecer e visualizar, pelos gestos e pela entonação da voz, os sentimentos que Lídia tinha sobre os torturadores. Ela desejou que eles sentissem remorsos do que fizeram e que tal isso pudesse consumir a paz de espírito deles, no entanto, como lembrou sua terapeuta, remorsos tinha ela, dos desdobramentos na sua vida, da arbitrariedade e da violência do estado repressor.

Para finalizar, gostaríamos de refletir sobre o modelo de militância assumido por Lídia. Uma militância sem vínculos com partidos ou organizações, norteada por princípios subjetivos de decisões e entrelaçada por legados familiares. No passado, Lídia constituiu para si uma militância distinta das demais mulheres, no presente tal informação evidência a pesquisa histórica que houve uma gama de possibilidades de ativismo político feminino durante a ditadura no estado. Marcelo Ridenti (1990) em seu estudo sobre a militância feminina no período da ditadura, apresenta as diferenciadas formas como as mulheres interviram na cena política brasileira, construindo protagonismos conservadores de apoio a ditadura 
militar, ${ }^{10}$ protagonismos de oposição feministas e protagonismos de oposição distanciados do feminismo, definidos como femininos (RIDENTI, p. 122).

Portanto, ao evidenciarmos a trajetória política de Lídia sem atrelamentos, contribuímos para a construção de uma abordagem que estima o potencial de participação feminina no período, permitindo pensar suas atuações para além da história dos partidos, das organizações de esquerda e da luta armada. Desta feita, tal perspectiva contribui em muito para o debate desenvolvido no início do artigo, a importância em refutar o ocultamento dos protagonismos femininos no quadro da produção historiográfica sobre o período ditatorial no Paraná.

$\mathrm{Na}$ esteira de visibilidades, compreendemos ser importante dar ênfase a outros modelos de resistência a ordem estabelecida. Mas, primeiramente convidamos o(a) leitor(a) a conhecer mais uma passagem da vida da narradora:

\begin{abstract}
Alguém desse movimento estudantil conseguiu que eu fosse ficar por alguns dias em um apartamento de uns estudantes de medicina. Tem um fato interessantíssimo, eu fui para lá sem conhecer ninguém e fiquei no apartamento meio bagunçado que moram só rapaziada, e como eu não podia sair para a rua eles trouxeram as comidas e deixaram lá, eu fui arrumando tudo, era uma terapia danada, limpei chão, lavei banheiro, uma coisa boa assim. Quando chegou à noite, chegaram duas moças com uns trajes assim bem diferentes. Elas muito agressivas, extremamente agressivas, minissaias, bem assim tipo garota de programa mesmo, pintadíssimas. Me viram ali, me hostilizaram extremamente. 'Quem é você?'. 'Ah, eu sou estudante'. 'Não o
\end{abstract}

\footnotetext{
10 Sobre a formação de associações femininas conservadoras durante a ditadura civil-militar no Paraná, Reginaldo Cerqueira Sousa (2018) ao estudar a União Cívica Feminina Paranaense - UCF-PR, estabelece que tais uniões tinham como elemento agregador, o civismo. Eram formadas por mulheres de classe média e alta que se identificavam com um único modelo de gênero feminino: mulheres esposas, mães de famílias e dedicadas a prática política a partir do sentimento de patriotismo. Conforme ainda o autor, a participação política dessas mulheres foi ativa e dinâmica, "motivadas por interesses variados, fossem eles relacionados com a proteção da família e da pátria, fossem eles atrelados à preservação dos valores morais contra todos os comportamentos imorais. As mulheres demonstraram confiança nos militares apoiando um modelo de governo mais centralizador e capaz de impor a ordem" (Ibidem, p. 408).
} 
que você está fazendo aqui?'. Meu Deus, àquela hora começou me bater o desespero, porque ali na frente estava o quartel que tinha decretado a minha preventiva, na DOPS eu já era conhecida. [...] Aí eu disse: "olha meninas, o negócio é o seguinte eu vou abrir o jogo com vocês e a minha segurança está nas mãos de vocês, eu vou contar porquê que eu estou aqui'. 'Conta, conta'. Mas assim, o tom de voz muito hostil, muito provocativo, assim de menosprezo, muito ruim. Eu disse assim: 'olha, eu sou estudante de Sociais, eu moro na Casa do Estudante, eu participo do Movimento Estudantil'. 'Ah, desses baderneiros da rua?'. Era tudo neste vocabulário para pior. Eu digo: 'hoje em dia todo mundo é preso sem culpa nenhuma'. Ela disse: 'disso aí a gente entende. Isso é para tirar a grana. De nós é para tirar grana, a polícia'. Não sei não, era prostituta, polícia prendia, tomava a grana delas. De prisão elas entendiam. De prisão comum, não a política. Expliquei tudo como era essa história, elas tinham visto a tal bagunça entre aspas, que elas falaram, que eram as passeatas que a polícia já prendia todo mundo que estivesse por ali, participante ou não. Esse nosso papo levou umas duas três horas. Resultado, elas acabaram chorando, eu chorando, elas me abraçavam, me abraçavam, eram assim tipo minhas irmãs de coração, foi assim muito importante. Eu tinha um vestido só, era só um vestido que eu tinha. E o meu rosto já era bem conhecido, assim foram buscar comida para mim, tudo. Elas me trouxeram um lenço de seda, a estampa era de cavalo de corrida, coisa de jóquei, de seda aqueles lenções grandes para eu amarrar, amarrado porque elas sabiam muito de maquiagem, você não pode sair assim, você está com a cara muito lavada. Trouxeram um batom assim quase roxo, eu digo: 'ai meu Deus'. Pintaram os cílios tudo, tudo. Aquele o rímel, me trouxeram blusas tudo, camisetas, outras roupas, fizeram uma malinha, uma sacolinha de coisa, porque eu só tinha aquela roupa. Roupa íntima tudo elas me trouxeram. Você veja, a franqueza dê se dizer. Porque eu disse: 'oh meninas, o negócio é o seguinte: eu estou sendo procurada pela polícia'. A DOPS já andava atrás de mim assim direto. Disse assim: 'fica na consciência de vocês, se vocês chegarem ali no DOPS', elas não sabiam bem o que era o DOPS, a polícia, 'e vocês falarem já vão me levar daqui. Vocês não acreditam que eu não conheça a rapaziada daqui, mas eu não conheço'. Daí falei tudo isso e tal. Nossa, foi uma solidariedade, assim Carla, agora de ver o ser humano. O que é 
o ser humano? Tem o doutor, sabe o acadêmico, a prostituta, o padeiro. Quem vale mais? Para mim, elas. Professores meus não me deram guarida. Não só para mim como para algumas meninas da Filosofia. A maioria era mulher lá. [...] Sabe de te aparar, a gente falava e chorava e falava e chorava. Elas disseram: "você também pode ser presa, por outro motivo. Mas a cadeia é muito ruim, se você não tiver grana, você não sai'. Ainda eu disse: 'no meu caso nem grana não resolve. Não, resolve, não revolve!' (LUCASKI).

Apesar do fragmento ser um pouco extenso, o momento narrado por Lídia é significativo para tratarmos de protagonismos femininos. O episódio apresenta uma cena vivida por três mulheres. Uma mulher que escolheu para si a militância e outras duas que não se identificaram com a militância política. Mas, somente Lídia teria um protagonismo de resistência à ditadura militar? Entendemos que, as prostitutas apesar de não serem procuradas ou presas por envolvimentos com a lutas políticas, sentiram em suas vidas e corpos as consequências de um estado repressor, violento e violador dos Direitos Humanos e, no cotidiano, construíram protagonismos de resistências à ditadura. Muitas dessas resistências foram construídas pela necessidade de sobrevivência, mas também pelo afeto, pela solidariedade, cumplicidade e identificações com o gênero feminino.

Lídia recordou o momento com muita emoção, o sentimento de gratidão pelas irmãs de coração permanecia. No presente, relembrar era uma forma de agradecer, não deixar esquecer a atitude delas. Assim, por mais que tais mulheres, naquele momento, não estivessem na linha de frente do combate à ditadura, quando protegeram Lídia, militaram contra a ditadura.

Contudo, os estudos sobre a memória de mulheres no período da ditadura raramente evidenciam histórias de mulheres que, mesmo não estando vinculadas a luta política, tiveram consequências traumáticas em suas vidas. Suas histórias ainda seguem totalmente desconhecidas. No Paraná, suas memórias não foram contempladas nas tribunas e no relatório da Comissão Estadual da Verdade - Teresa Urban. Conforme Claudia Cristina Hoffmann (2019) as memórias femininas selecionadas para o relatório foram de mulheres brancas, intelectuais, militantes, cristãs escolarizadas e "de família". Sobre o caso da violência contra as 
prostitutas, encarceradas com Teresa Urban, na delegacia de Vigilância e Captura em Curitiba, citado pela própria Teresa no seu depoimento à Comissão (PARANÁ, 2014, p. 07), Claudia questiona quais seriam os motivos da memória dessas mulheres não terem sido um dos objetivos de investigação da Comissão da Verdade. E define que,

a seleção de algumas histórias que compõem o relatório da CEV revela o caráter político da memória. O exemplo das prostitutas silenciadas e esquecidas nos permite refletir sobre a continuidade dos preconceitos e sobre a violência desses esquecimentos, constituídos, ainda atualmente, como uma consequência dos tentáculos ditatoriais, uma manutenção enraizada, estrutural e naturalizada por um sistema, mesmo que os agentes das novas construções de memória assim não o intencionem (2019, p. 190).

\section{Considerações finais}

A narrativa de si de Lídia reconstrói o próprio passado, avalia as experiências vividas e, por conseguinte, dá sentido ao presente. Como observa Leonor Arfuch, "a narração de uma vida, longe de vir 'representar' algo já existente, impõe sua forma (e seu sentido) à própria vida" (2010, p.33). Portanto, na narrativa, Lídia reinventou sua subjetividade a partir de sua trajetória, dos conflitos, frustações e vitórias vividas, mas também dos ressentimentos sobre o passado. Ressentimentos que no presente, reaparecem em reafirmações que, se não foram motivações para contar sobre si, foram elementos constitutivos da narrativa.

Lídia somente conseguiu retornar ao Brasil em 1973, quando absolvida pela Justiça Militar dos processos que foi indiciada. Com a legalidade, voltou para a sua casa em Araucária. Ela havia passado por muitas coisas. Não era mais a mesma, mas a militância era algo que ela não havia perdido. Estava lá. Ela somente precisava saber em que luta iria se engajar. 
Constituir um percurso historiográfico sobre a atuação de uma militante política para escrever sobre a ditadura no Paraná é refutar a invisibilidade de protagonismos femininos, mas também é conhecermos como as mulheres se constituíram como sujeitos políticos em um determinado período da história. Como suas memórias construíram e constroem um lugar político a partir do ato de tomar notas sobre si e, em paralelo, criam novas formas de ação política no presente.

Lídia, associando militância e meio ambiente, se tornou ambientalista. Atualmente é coordenadora da Associação de Defesa do Meio Ambiente de Araucária - AMAR, uma organização não governamental de defesa da justiça ambiental. Por seu engajamento, recebeu o Prêmio Mãe Natureza, realizado pela Secretaria Estadual do Meio Ambiente e Recursos Hídricos do Estado do Paraná. No presente, ela reafirma seu desejo de continuar a mudar o mundo, mais justo e igualitário, ao declarar, no recebimento do Prêmio, que "esta premiação é apenas o primeiro passo para que outras pessoas continuem trabalhando por um mundo melhor". ${ }^{11}$

\section{Referências}

ARFUCH, Leonor. O espaço biográfico: dilemas da subjetividade contemporânea. Rio Janeiro: EDUERJ, 2010.

ARFUCH, Leonor. Narrativas del yo y memorias traumáticas. Tempo e argumento. Florianópolis, v. 4, n. 1, p. 45-60, jan./jun. 2012.

BRUNELO, Leandro. Operação Marumbi no Estado do Paraná. In: PRIORI, A. et al. História do Paraná: séculos XIX e XX [on-line]. Maringá, PR: Eduem, 2012.

CHARTIER, Roger. A visão do historiador modernista. In: FERREIRA, M.; AMADO, J. (Orgs.) Usos \& abusos da história oral. Rio de Janeiro: Editora da Fundação Getúlio Vargas, 1996.

$11 \mathrm{https://carollinasalle.jusbrasil.com.br/noticias/114084980/a-antropologa-e-ambientalista-lidia-lucaski-}$ recebe-o-premio-mae-natureza. Acesso em 05/09/2019. 
CONRADI, Carla Cristina Nacke. Memórias do sótão: vozes de mulheres na militância política contra a ditadura no Paraná (1964-1985). Curitiba, 2015. 266 p. Tese (Doutorado em História), Universidade Federal do Paraná.

FOUCAULT, Michel. A escrita de si. In: FOUCAULT, Michel; MOTTA, Manoel Barros da. Ética, sexualidade, política. Rio de Janeiro, RJ: Forense Universitária, 2006.

HOFFMANN, Claudia Cristina. Comissão Estadual da Verdade do Paraná Teresa Urban: depoimento sobre memória e um esquecimento. In: GONÇALVES, Marcos, BREPOHL, Marion (Orgs.). Políticas de memória e experiências de (des)exílio. Curitiba: Ed. UFPR, 2019.

PARANÁ. Relatório da Comissão Estadual da Verdade - PR: Teresa Urban. Curitiba, 2014. Disponível em: https://www.memoriaedireitoshumanos.ufsc.br. Acesso em 05/10/2019.

PERROT, Michelle. Práticas da memória feminina. Revista Brasileira de História, v. 9, n. 18, p. 9-18, ago./set. 1989.

PORTELLI, A. Tentando aprender um pouquinho: algumas reflexões sobre a ética na história oral. Projeto História. São Paulo, n. 15, abr. 1997.

RAGO, Margareth. A aventura de contar-se. Feminismo, escrita de si e invenções da subjetividade. Campinas: Editora Unicamp, 2013.

RAGO, Margareth. Epistemologia feminista, gênero e história. In: PEDRO, Joana; GROSSI, Miriam (Orgs.). Masculino, feminino, plural. Florianópolis, SC: Editora Mulheres, 1998.

RIDENTI, Marcelo Siqueira. As mulheres na política brasileira: os anos de chumbo. Tempo Social. USP, São Paulo, v. 2, n. 2, p. 113-128, 2º sem. 1990.

SOUZA, Reginaldo Cerqueira. Associativismo feminino e participação política: um estudo sobre as bases sociais de apoio à ditadura militar em Curitiba (1964-1985). Estudos Históricos. Rio de Janeiro. V.31, n. 65, p. 389-412, set-dez 2018.

SCOTT, Joan. Gênero: uma categoria útil de análise histórica. Educação e Realidade. Porto Alegre, vol.16, n. 2, 1990.

SÊGA, Rafael Augustus. Tempos Belicosos: A Revolução Federalista no Paraná e a rearticulação da vida político-administrativa do Estado (1889-1907). Curitiba: Aos Quatro Ventos; CEFET-PR, 2005. 
SWAIN, Tânia Navarro. História: construção e limites da memória social. In: RAGO, Margareth; FUNARI, Pedro Paulo (Orgs.). Subjetividades antigas e modernas. São Paulo: Annablume, 2008.

RECEBIDO EM: 10/09/2019

APROVADO EM: 06/10/2019 